\title{
PENGARUH pH DAN KATION TERHADAP AKTIFITAS ENZIM 乃-GLUKOSIDASE YANG DIHASILKAN DARI A. foetidus (Naka.)
}

\author{
Trirakhma Sofihidayati \\ Program Studi Farmasi FMIPA Universitas Pakuan Bogor \\ Email: sofihidayati9@gmail.com
}

\begin{abstract}
ABSTRAK
Selulase adalah enzim yang terlibat dalam proses degradasi selulosa. Enzim ini merupakan campuran dari enzim endoglukanase, eksoglukanase, dan $\beta$-glukosidase. Limbah agro industri yang diolah menggunakan kapang Aspergillus foetidus diperkirakan dapat dimanfaatkan sebagai sumber enzim selulase untuk mendegradasi limbah dengan biaya yang lebih murah. Penelitian ini bertujuan untuk mengetahui pengaruh $\mathrm{pH}$ dan kation terhadap aktivitas enzim $\beta$-glukosidase yang dihasilkan dari kapang A. foetidus (Naka.). Hasil penelitian menunjukan bahwa enzim $\beta$-glukosidase dari $A$. foetidus yang diinkubasi pada suhu ruang di medium yang mengandung 3\% polard selama 6 hari menghasilkan aktivitas sebesar $3.56 \mathrm{U} / \mathrm{mL}$. Aktivitas optimum enzim $\alpha$-glukosidase terjadi pada kondisi medium dengan pH 5.0 dan suhu $60^{\circ} \mathrm{C}$. Enzim $\alpha$-glukosidase relatif stabil pada $\mathrm{pH} 4,2-5,0$ dan suhu penyimpanan 28 dan $40^{\circ} \mathrm{C}$, tetapi tidak stabil pada suhu $80{ }^{\circ} \mathrm{C}$. Aktivitas $\beta$-glukosidase meningkat dengan adanya penambahan kation-kation $\mathrm{Mg}^{2+}, \mathrm{Ba}^{2+}$, dan $\mathrm{Mn}^{2+}$ dengan konsentrasi akhir $1 \mathrm{mM}$ dan $5 \mathrm{mM}$. Penambahan $1 \mathrm{mM}$ ion $\mathrm{Fe}^{2+}$ menurunkan aktivitas enzim, tetapi penambahan $5 \mathrm{mM}$ ion $\mathrm{Fe}^{2+}$ meningkatkan aktivitas enzim sebesar 39\%.
\end{abstract}

Kata kunci: Enzim $\alpha$-glukosidase, A. foetidus, degradasi selulosa

\section{THE EFFECT OF pH AND ADDITION OF CATIONS ON THE ACTIVITES OF 乃-GLUKOSIDASE PRODUCED FROM Aspergillus foetidus (Naka.)}

\begin{abstract}
The $\alpha$-glucosidase is the enzyme involved in the degradation process of cellulose. This enzyme was expected could be produced from the fermentation of agro-industry waste product using $A$. foetidus (Naka.) mold. This study was aimed to determine the effect of $\mathrm{pH}$ and additionof cations on the activity of $\alpha$-glucosidase enzyme from $A$. foetidus. The results show that the highest activity of $\beta$-glukosidase produced from $A$. foetidus which was grown on the medium contained 3\% wheat pollard in room temperature reached at days 6 of incubation period. The activity was as much as 3.56 $\mathrm{U} / \mathrm{mL}$. The optimum activity $\beta$-glucosidase was reached at $\mathrm{pH} 5.0$ and temperature $60^{\circ}$ C. The stable condition of the $\beta$-glucosidase is observed in the $\mathrm{pH}$ ranged from 4.2 to 5.0. Addition of $\mathrm{Mg}^{2+}, \mathrm{Ba}^{2+}$, and $\mathrm{Mn}^{2+\mathrm{c}}$ cations at concentration of $1 \mathrm{mM}$ and $5 \mathrm{mM}$ proved increasing the activity of the enzyme meanwhile addition of $1 \mathrm{mM} \mathrm{Fe}^{3+}$ decreased the activity of the enzyme. On the contrary, the addition of $5 \mathrm{mM}$ increases the enzyme activity up to $39 \%$.
\end{abstract}

Keywords : $\beta$-glucosidase, A. foetidus, cellulose degradation 


\section{PENDAHULUAN}

Selulase adalah enzim yang terlibat dalam proses degradasi selulosa, yaitu komponen utama yang memiliki polimer ikatan $\beta$ antar molekul glukosa didalamnya. Enzim ini merupakan campuran dari enzim endoglukanase, eksoglukanase, dan $\beta$-glukosidase. Enzim $\beta$-glukosidase memutuskan ikatan $\beta(1 \rightarrow 4)$ glikosida antara 2 molekul glukosa atau molekul selobiosa dan mengkatalis proses hidrolisis residu ujung non pereduksi pada $\beta$-D-glukosa dengan melepaskan unit glukosa. Enzim selulase dibutuhkan oleh organisme seperti jamur, bakteri, rayap, maupun hewan ruminansia untuk bisa mengkonsumsi senyawa selulosa. Saat enzim endoglukanase dan eksoglukanase mendegradasi selulosa, akan dihasilkan molekul selobiosa yang pada akhirnya akan menghambat aktivitas kerja enzimenzim tersebut. Pada fase ini dibutuhkan peranan enzim $\beta$-glukosidase untuk dapat menghidrolisis selobiosa menjadi senyawa yang lebih sederhana yaitu glukosa. Beberapa penelitian melaporkan bahwa limbah agro industri dapat menjadi substrat yang baik untuk memproduksi enzim $\alpha$-amilase dan $\beta$-glukosidase. Penelitian-penelitian lain juga menunjukkan bahwa beberapa spesies kapang juga dapat menghasilkan enzimenzim ini. Limbah agroindustri dan kapang jika digunakan secara bersamaan keduanya diperkirakan dapat digunakan secara sinergis untuk meningkatkan daya degradasi limbah-limbah pertanian dengan biaya yang lebih murah, karena penggunaan enzim komersial untuk proses degradasi limbah pertanian dan industri sangat tidak ekonomis (Rajasekar, 2013).

Penelitian ini bertujuan untuk mengetahui pengaruh $\mathrm{pH}$ dan kation terhadap aktivitas enzim $\alpha$-glukosidase yang dihasilkan dari kapang $A$. foetidus.

\section{METODE PENELITIAN} Bahan
Isolat kapang $A$. foetidus (Naka.) koleksi Balai Penelitian Ternak Ciawi. pollard (dedak gandum untuk pakan ternak) dari PT. Indofeed-Bogor, potato dextrose agar (PDA), medium Manels, medium Dubos.

\begin{abstract}
Alat
Alat-alat yang digunakan adalah pipet mikro, autoklaf, alat sentrifugal berpendingin, spektrofotometer, jarum ose, $\mathrm{pH}$ meter, vorteks, neraca analitik, rotary shaker, blender, dan peralatan gelas.
\end{abstract}

\section{CARA KERJA \\ Pembuatan Polard NaOH}

Kedalam 1 liter larutan $\mathrm{NaOH} 0.5 \%$ (b/v) ditambahkan sebanyak 50 gram polard kering. Campuran dididihkan selama 60 menit dalam penangas air. Setelah didinginkan sampai suhu kamar, campuran disaring dengan kain tipis dan dicuci dengan air sampai air perasan mempunyai $\mathrm{pH}$ netral. Selanjutnya polard $\mathrm{NaOH}$ dikeringkan dengan blower pada suhu $40^{\circ}$ C. Polard yang telah kering kemudian digiling dengan blender.

\section{Produksi Enzim B-glukosidase}

Isolat A. foetidus untuk memproduksi enzim $\alpha$-glukosidase ditanam pada media agar miring PDA dan diinkubasi selama 5 hari (Haryati et al. 1997). Spora yang dihasilkan kemudian disuspensikan ke dalam $5 \mathrm{~mL}$ larutan $\mathrm{NaCl}$ $0.85 \%$ menjadi larutan inokulum. Sebanyak $2 \mathrm{~mL}$ larutan inokulum diinokulasikan pada $50 \mathrm{~mL}$ media Mandels yang mengandung $3 \%$ polard $\mathrm{NaOH}, 0.3 \%$ ekstrak khamir, dan $0.075 \%$ bacto pepton, selanjutnya diinkubasi pada suhu kamar dalam inkubator bergoyang dengan kecepatan $150 \mathrm{rpm}$ selama 6 hari. Untuk mengetahui aktivitas enzim, dilakukan pengujian pada hari ke 5, 6 dan 7 .

Penentuan Aktivitas $\beta$-glukosidase 
Aktivitas enzim $\beta$-glukosidase ditentukan dengan mengukur pelepasan $p$ nitrofenol dari $p$-NPG (Lin et al. 1999). Filtrat enzim, larutan buffer asetat pH 5.0 dan substrat $p$-NPG $0.3 \%(\mathrm{~b} / \mathrm{v})$ diinkubasi selama 60 menit pada suhu $50{ }^{\circ} \mathrm{C}$. Absorban diukur pada panjang gelombang $400 \mathrm{~nm}$.

\section{Penentuan pH dan Suhu Optimum Enzim}

Penentuan $\mathrm{pH}$ optimum dilakukan dengan menguji aktivitas enzim pada kisaran $\mathrm{pH}$ 4.2, 4.6, 5.0, 5.4, 5.8 dan 6.2. Sedangkan penentuan suhu optimum dilakukan dengan menguji aktivitas enzim pada variasi suhu $40,50,55,60,65$, dan $70^{\circ} \mathrm{C}$.

\section{Penentuan pH Stabilitas enzim}

Penentuan $\mathrm{pH}$ stabilitas dilakukan dengan menginkubasi enzim dalam buffer asetat $(\mathrm{pH} \mathrm{4.2,} \mathrm{4.6,} \mathrm{5.0,} \mathrm{5.4,} \mathrm{5.8,} \mathrm{dan} \mathrm{6.2)}$ pada suhu optimum selama 30 menit. Setelah inkubasi berakhir, aktivitas enzim ditentukan pada kondisi $\mathrm{pH}$ optimum dan suhu optimum.
Aktivitas enzim $\beta$-glukosidase ditentukan dengan mengukur pelepasan $p$ nitrofenol dari $p$-NPG. Absorbansi diukur pada panjang gelombang $400 \mathrm{~nm}$. Kadar $p$ nitrofenol yang dihasilkan ditentukan berdasarkan kurva standar. Aktivitas $\beta$ glukosidase dinyatakan dalam satuan Unit/mL Satu unit aktivitas enzim didefinisikan sebagai jumLah enzim yang dibutuhkan untuk mengkatalisis pembentukan satu mikromol $\left(10^{-6} \mathrm{~mol}\right) p$ nitrofenol per-menit pada kondisi percobaan.

\section{Penetapan Aktivitas Enzim Terhadap Pengaruh Kation}

Pengaruh ion logam ditentukan dengan menambahkan masing-masing, $\mathrm{FeCl}_{3}, \mathrm{MgCl}_{2}, \mathrm{BaCl}_{2}$, dan $\mathrm{MnCl}_{2}$ dengan konsentrasi akhir 1 dan $5 \mathrm{mM}$ dalam campuran reaksi. Komposisi campuran reaksi terdiri dari, enzim, substrat $p$-NPG $0.3 \%$, dan bufer asetat, selanjutnya diinkubasi selama 1 jam pada kondisi suhu dan $\mathrm{pH}$ optimum. Aktivitas $\beta$-glukosidase ditentukan dengan mengukur pelepasan $p$ nitrofenol dari $p$-NPG.

$$
\text { Aktivitas } \beta \text {-glukosidase }=\frac{[\text { nitrofenol }] \text { sampel }(\mu \mathrm{g} / \mathrm{mL})-[\text { nitrofenol }] \text { kontrol }(\mu \mathrm{g} / \mathrm{mL})}{\text { Waktu inkubasi }(\text { menit }) \times \text { BMnitrofenol }(139 \mu \mathrm{g} / \mu \mathrm{mol})} \times \mathrm{fp}
$$

\section{HASIL DAN PEMBAHASAN}

Penentuan pH dan Suhu Optimum Enzim

Penetapan $\mathrm{pH}$ maupun suhu optimum mutlak dilakukan sebagai prasyarat penetapan aktivitas enzim karena perubahan suhu maupun $\mathrm{pH}$ dapat mempengaruhi stabilitas enzim ataupun afinitas enzim sebagai aktivator dan inhibitor. Dengan diketahuinya $\mathrm{pH}$ dan suhu optimum, aktifitas selulolitik yang mikroba dapat diaplikasikan secara optimal untuk mendegradasi selulosa secara maksimal

Hasil uji penetapan aktivitas enzim $\beta$-glukosidase isolat kapang A. foetidus diperoleh data bahwa aktifitas optimum enzim sebesar $2.76 \mathrm{U} / \mathrm{mL}$ dicapai pada hari inkubasi ke 6. Gambar 1 menampilkan aktivitas enzim $\beta$-glukosidase pada lama inkubasi yang berbeda. 


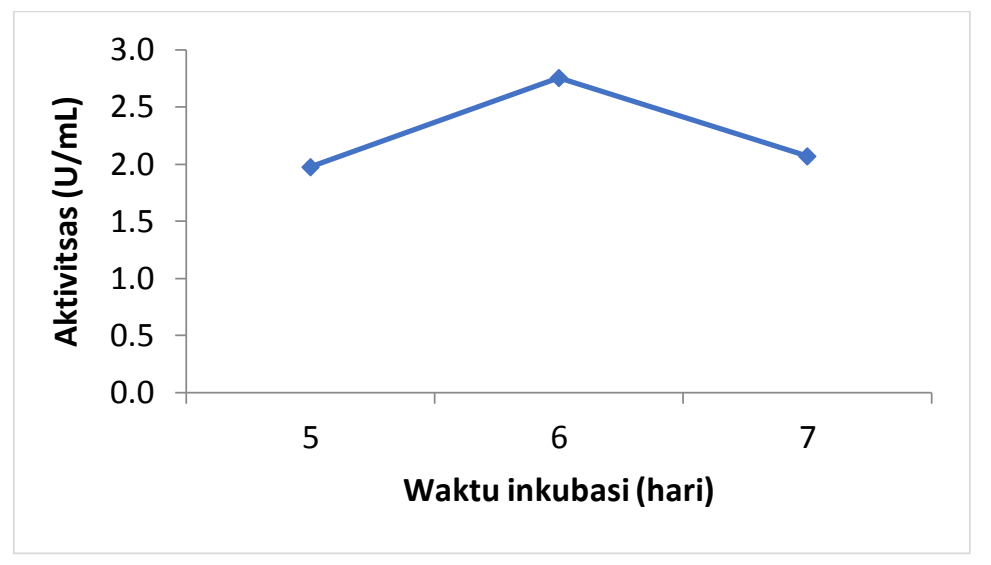

Gambar 1. Aktivitas $\beta$-glukosidase terhadap variasi waktu inkubasi

Pengujian aktivitas enzim $\alpha$ glukosidase pada berbagai kondisi $\mathrm{pH}$ ditampilkan Gambar 2. Pada gambar terlihat bahwa $\beta$-glukosidase mempunyai $\mathrm{pH}$ optimum 5.0, dengan aktivitas sebesar $2.13 \mathrm{U} / \mathrm{mL}$. Pada $\mathrm{pH}$ 5.2, aktivitasnya turun sebesar $61 \%$ menjadi $0.81 \mathrm{U} / \mathrm{mL}$, sedangkan pada $\mathrm{pH} 4.8, \beta$-glukosidase mempunyai aktivitas sebesar $1.15 \mathrm{U} / \mathrm{mL}$. Sebagian besar kapang umumnya mempunyai $\mathrm{pH}$ optimum dibawah 7 , dan sebagian besar enzim umumnya mempunyai $\mathrm{pH}$ optimum antara 4-8. Pada penelitian sebelumnya, Setyaningsih (2007) menyatakan bahwa pH optimum enzim $\beta$-glukosidase yang dihasilkan $A$. niger adalah 4.5, sedangkan Oktavia (2014)) menemukan aktivitas optimum $\beta$ glukosidase pada isolat kapang $E N$ (isolat dari Enhalus sp) yang dikulturkan pada media yang mengandung limbah agar-agar terjadi pada $\mathrm{pH}$ 4. Penelitian lainnya juga menunjukan bahwa $\mathrm{pH}$ optimum enzim selulase dari bakteri yang diisolasi dari limbah rumput laut adalah pada $\mathrm{pH} 5.0$ Dini (2017).

Selain $\mathrm{pH}$, suhu medium juga dapat mempengaruhi aktivitas enzim. Pada Gambar 3, terlihat bahwa $\beta$-glukosidase mempunyai suhu optimum $60^{\circ} \mathrm{C}$, dengan aktivitas sebesar $3.56 \mathrm{U} / \mathrm{mL}$. Pada kondisi diatas suhu optimum, aktivitas $\beta$ glukosidase menurun $68 \%$, menjadi 1.12 $\mathrm{U} / \mathrm{mL}$, bahkan pada suhu $70^{\circ} \mathrm{C}$, aktivitasnya tinggal $13 \%$ atau sebesar 0.45 $\mathrm{U} / \mathrm{mL}$. Namun pada kondisi sedikit dibawah dibawah suhu optimum, yaitu pada suhu $50^{\circ} \mathrm{C}$, aktivitas enzim $\beta$ glukosidase relatif stabil, walaupun aktivitasnya turun sebesar $51 \%$ menjadi $1.74 \mathrm{U} / \mathrm{mL}$, sedangkan pada suhu $40^{\circ} \mathrm{C}$ aktivitasnya hanya $0.95 \mathrm{U} / \mathrm{mL}$. Suhu optimum pada penelitian ini sesuai dengan hasil penelitian Setyaningsih (2007) yang menemukan suhu $60^{\circ} \mathrm{C}$ sebagai suhu optimum aktivitas enzim $\beta$-glukosidase yang dihasilkan oleh A.niger. 


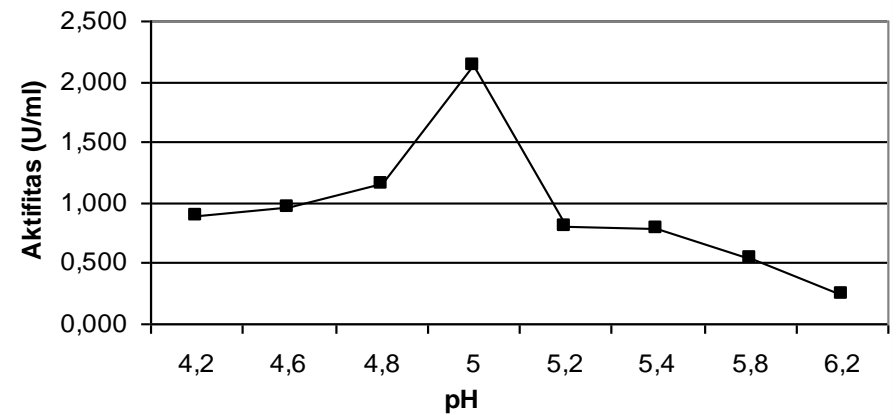

Gambar 2. Aktivitas $\beta$-glukosidase terhadap variasi $\mathrm{pH}$

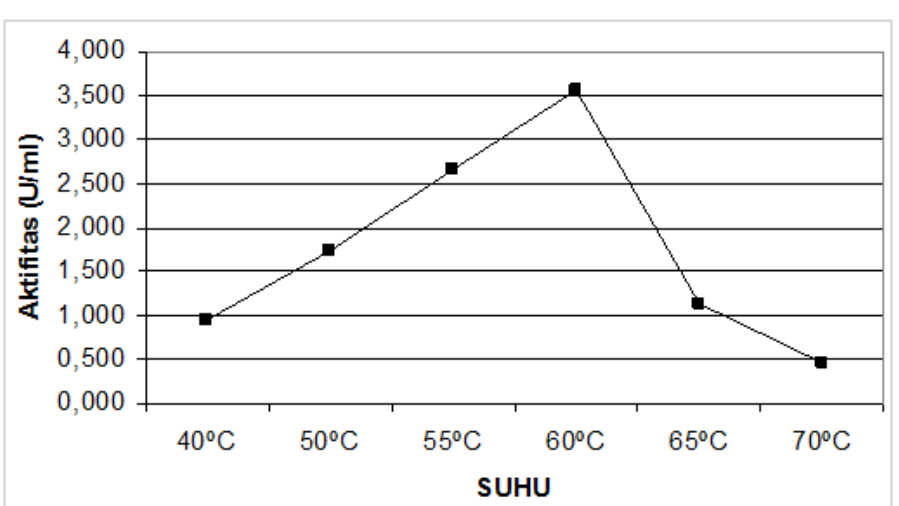

Gambar 3. Aktivitas $\beta$-glukosidase terhadap variasi suhu

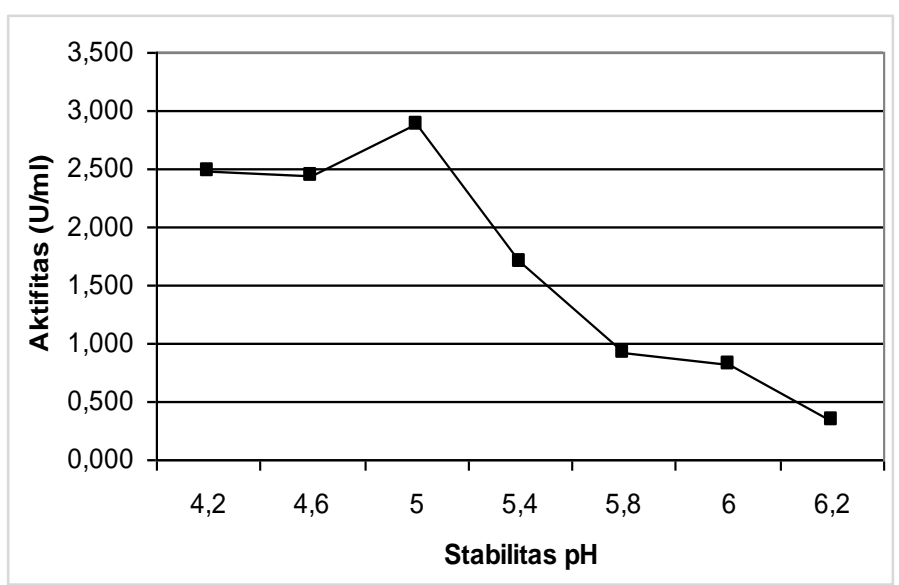

Gambar 4. Stabilitas $\beta$-glukosidase terhadap variasi pH 


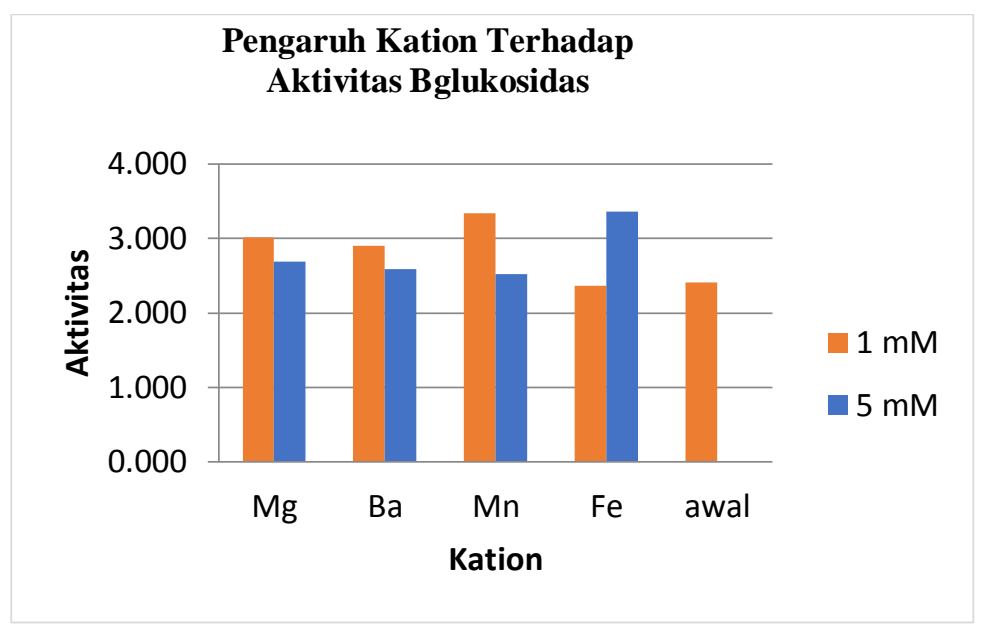

Gambar 5. Pengaruh kation terhadap aktivitas $\beta$-glukosidase

Peningkatan aktivitas enzim yang tajam, yaitu $46 \%$ pada $\mathrm{pH}$ optimum berkaitan dengan perubahan yang terjadi pada struktur atau muatan gugus ionik enzim yang terdapat pada sisi aktif enzim. Hal ini mengakibatkan konformasi sisi aktif enzim menjadi lebih efektif dalam mengikat substrat, yang selanjutnya akan diubah menjadi produk. Pada $\mathrm{pH}$ yang rendah enzim akan mengalami protonisasi sehingga kehilangan muatan negatifnya, sedangkan pada $\mathrm{pH}$ yang tinggi substrat akan mengalami ionisasi dan kehilangan muatan positifnya. Dengan berubahnya muatan, maka struktur tersier atau kuarterner akan berubah, akibatnya protein $\beta$-glukosidase akan terbuka dan kehilangan aktivitasnya.

Pengaruh kation terhadap aktivitas $\beta$ glukosidase

Pengaruh kation terhadap aktivitas enzim $\beta$-glukosidase yang dikarakterisasi menggunakan senyawa-senyawa $\mathrm{FeCl}_{3}$, $\mathrm{MgCl}_{2}, \mathrm{BaCl}_{2}$, dan $\mathrm{MnCl}_{2}$ ditampilkan pada Gambar 5. Penambahan $1 \mathrm{mM}$ dan 5 $\mathrm{mM}$ masing-masing senyawa $\mathrm{MgCl}_{2}$, $\mathrm{BaCl}_{2}$, dan $\mathrm{MnCl}_{2}$ dapat meningkatkan aktivitas $\quad \beta$-glukosidase, sedangkan penambahan $1 \mathrm{mM} \mathrm{FeCl}_{3}$ menurunkan aktivitas $\beta$-glukosidase sebesar $2 \%$. Namun penambahan $5 \mathrm{mM}$ senyawa $\mathrm{FeCl}_{3}$ ternyata mampu meningkatkan aktivitas $\beta$ - glukosidase hingga $60 \%$. Hasil penelitian ini sejalan dengan hasil-hasil penelitian sebelumnya yang menunjukan bahwa aktivitas enzim selulase yang dihasilkan oleh bakteri yang diisolasi dari limbah rumput laut juga dapat ditingkatkan dengan penambahan $10 \mathrm{mM} \mathrm{FeCl}_{3}$, sedangkan penambahan $10 \mathrm{mM}$ kation $\mathrm{Zn}^{2+}$ justru menurunkan aktivitas enzim (Dini, 2017).

Sebagian enzim mengandung ion logam yang terikat erat atau memerlukan ion logam untuk aktivitasnya. Ion logam dapat meningkatkan pengikatan substrat dan proses katalisis dengan membentuk beberapa jenis komplek jembatan dari enzim, logam dan substrat. Tetapi kelebihan ion logam dapat menghambat aktivitas enzim karena senyawa nukleotida di- dan tri-fosfat yang membentuk kompleks yang stabil dengan kation tersebut. Selain ion $\mathrm{Fe}^{3+}$ dan $\mathrm{Mg}^{2+}$ yang berfungsi dalam protein heme, ion-ion logam yang paling sering terlibat dalam katalisis enimatik adalah $\mathrm{Mn}^{2+}$ dan $\mathrm{Ca}^{2+}$. Keempat kation tersebut bekerja mengaktifkan enzim selulase dari bakteri PMP-0126Y (Munifah, 2013).

\section{SIMPULAN}

Aktivitas $\beta$-glukosidase maksimum dari A. foetidus (Naka.) dihasilkan pada hari ke 6 inkubasi pada media Mandels dengan penambahan $3 \%$ polard. Nilai $\mathrm{pH}$ 
optimum bagi aktivitas $\beta$-glukosidase $A$. foetidus (Naka.) berada pada 5.0 dan dan suhu optimum pada $60{ }^{\circ} \mathrm{C}$. Betaglukosidase relatif stabil pada $\mathrm{pH} 4.2-5.0$ dan pada penyimpanan suhu $28^{\circ} \mathrm{C}$ dan 40 ${ }^{\circ} \mathrm{C}$, tetapi tidak stabil pada suhu $80{ }^{\circ} \mathrm{C}$. Aktivitas $\beta$-glukosidase meningkat dengan adanya penambahan kation-kation $\mathrm{Mg}^{2+}$, $\mathrm{Ba}^{2+}$, dan $\mathrm{Mn}^{2+}$ dengan konsentrasi akhir $1 \mathrm{mM}$ dan $5 \mathrm{mM}$, sedangkan penambahan $1 \mathrm{mM}$ ion $\mathrm{Fe}^{2+}$ justru menurunkan aktivitas enzim tetapi penambahan $5 \mathrm{mM}$ ion $\mathrm{Fe}^{2+}$ meningkatkan aktivitas sebesar 39\%.

\section{SARAN}

Perlu dilakukan penelitian lebih lanjut untuk megetahui bagaimana memproduksi dan mengisolasi enzim betaglukosidase dari $A$. foetidus, kemudian mengaplikasikanny secara optimal sebagai enzim selulase yang bermanfaat untuk mendegradasi limbah-limbah agroindustri.

\section{DAFTAR PUSTAKA}

Dini, I.R. dan I. Munifah. 2014. Produksi dan karaterisasi enzim selulase ekstrak kasar dari bakteri yang diisolasi dari limbah rumput laut. Jurnal Teknologi dan Industri Pertanian. 6(3).

Hermansyah, H. dan R. Rizky. 2014. Produksi enzim hidrolisis $\alpha$-amylase dan $\beta$-glukosidase dari Aspergillus niger dalam substrat sekam padi, bagas dan tongkol jagung dengan metode fermentasi solid. Rekayasa Bioproses. Program Studi Teknologi Bioproses, Departemen Teknik Kimia, Fakultas Teknik, Universitas Indonesia.

Oktavia, Y., A. Andhika, T. Nurhayati dan T. Kustiariyah. 2014. Karakterisasi enzim kasar selulase kapang Endofit dari lamun. Jurnal Ilmu dan Teknologi Kelautan Tropis. 6 (1): 200-218.

Rajasekar, A. 2013. Production and optimazation of amylases using Aspergillus niger. International Journal of Scientific and Engineering Research. 4(7): 2497.

Setyaningsih, D., K. Tresnawati1), M. T. Soehartono dan A. Apriyantono. 2007. Pengaruh aktivitas $\beta$ glukosidase eksternal dari kapang terhadap kadar vanilin buah vanili. Jurnal Teknologi Industri Pertanian. 16 (1): 28-35.

Munifah, I. 2014. Produksi dan karakterisasi enzim selulase dari limbah pengelolaan rumput laut. Jurnal Teknologi Pengelolaan Limbah. 16 (3): 221-228. 
